\title{
PREVALENCE OF HEPATITIS C VIRUS (HCV) AMONG THALASSEMIA PATIENTS IN IBN-ALBALADY HOSPITAL
}

\author{
Baydaa Ahmed Abed \\ National Diabetes Center. Al-Mustansiria University. \\ E-Mail: baydaaahmed@yahoo.com
}

\begin{abstract}
Background: thalassemia is one of most dangerous disease; it is an inherited impairment of hemoglobin production, in which there is partial or complete failure of the synthesis of globin chain.

Objective: the aim of this study is to determine the prevalence of Hepatitis C Virus (HCV) infection among thalassemic patients in Ibn-albalady hospital in Baghdad.

Patients and methods: The study was carried out on 111 transfusion dependent beta-thalassemia (74 males and 37 females) with a mean age 12.51 yrs attending to the Ibn - Alba lady Hospital, in Baghdad during the period March 2008 to September 2008. The control group was thirty - one (12 males and 19 females) with mean age of 11.5 yrs and investigated to serve as a control group; they were randomly selected from community. Blood sample was collected in morning for biochemical assays (hepatitis C virus (HCV), Glutamic Oxaloacetic (GOT), Glutamic Pyruvic Transaminase (GPT), Alkaline phosphates (ALP), Total serum bilirubin (TSB), Direct serum bilirubin( Dir.SB), Indirect serum bilirubin (Indir.SB).

Results: Out of 111 thalassemic patients there was 51 (46\%) sera was confirmed positive for antiHCV- antibodies. The remaining 60 (54\%) were seronegative, while among 31 healthy controls only one $(3.22 \%)$ was seropositive the result was statistically of a high significant difference $(\mathrm{P}=0.0001)$.Out of 51 seropositive, $13(72.3 \%)$ patients were positive among those above 20 years, while only one (16.7) was positive among those from $(0-4)$ years. It was found no significant correlation in (sex, TSB, Indir.SB, ALP) between patients with HCV+ve compared with HCV -ve. The current study demonstrated that there was a highly significant difference in (GPT, GOT, and Dir.SB) levels between patients with seropositive HCV and patients with seropositive HCV.

Conclusions: The main causes of liver injury in thalassemia are hepatitis $\mathrm{C}$ virus and the finding suggests that $\mathrm{HCV}$ is the main cause of abnormal liver function in patients with thalassemia.
\end{abstract}

Keywords: Prevalence, Thalassemia, Hepatitis-C virus.

\section{Introductio}

Thalassemias are a heterogeneous group of genetic disorders, which result from a reduced rate of synthesis of $\alpha$ or $\beta$-chain (1). In thalassemia, the imbalance of globin chain synthesis leads to red cell damage resulting in destruction of red cells in the marrow (ineffective erythropoiesis) and peripheral circulation (hemolysis) (2). There are two different chains of protein in the hemoglobin a molecule, $\alpha$ and $\beta$ and either can be affected (3). Thus, thalassemia is divided into $\alpha$-thalassemia, in which, the production of $\alpha$-globin is deficient, and $\beta$-thalassemia, in which, the $\beta$-globin production is defective (4). The most common type is $\beta$-thalassemia (5) alpha thalassemia is the reduction or absence of alpha chain synthesis and common in South East Asia. There are two alpha gene loci on chromosome 16 (6), and therefore each individual carries four alpha globin gene, two from the paternal chromosome and two from maternal chromosome. This result in four possible genotypes, each resulting in different clinical syndrome (7). If one is deleted, the silent carriers of $\alpha$-thalassemia in which there is no clinical effect is produced. If two are deleted the patient exhibit the feature of $\alpha$ - thalassemia trait in which there is a mild hypochromic anemia (8). $\beta$ thalassemia is an autosomal recessive disorder characterized by reduced or absent $\beta$ globin chain synthesis, which can be caused by one of 180 mutations in the gene coding for the $\beta$ chain of hemoglobin tetramer (9). The beta globin gene located on chromosome 11 (10). Hepatitis C 
virus (HCV) is a blood borne virus. Most epidemiological studies have focused on group at risk infection such as thalassemic patients through multiple blood transfusions. Moreover, $\mathrm{HCV}$ is now considered as the leading cause of post transfusion hepatitis world wide (11). The risk acquiring $\mathrm{HCV}$ infection as a result of transfusion was about $10 \%$ (12). Tt was found that the $\mathrm{HCV}$ is responsible for at least $90 \%$ of transfusion associated NANB (Non A Non B) hepatitis (13). Repeated blood transfusion in thalassemic patients is necessary for their survival; however, such transfusions increase the exposure not only to $\mathrm{HCV}$ but also other blood borne viruses (Hepatitis B virus (HBV), Hepatitis G virus (HGV), Human Immunodeficiency virus (HIV) (14). It was stated that the second commonest cause of death in thalassemic major patients over 15 years of age is liver disease, due to blood borne viral hepatitis (15). Interestingly, more studies addressed that patients, on long-term transfusion therapy, were at risk of experiencing $\mathrm{HCV}$ in a prevalence ranging from (12.2\%-16\%) (16). Furthermore, the infection with $\mathrm{HCV}$ may not induce immunity, in which they documented, that multiple distinct episodes of acute hepatitis were observed in individuals of poly transfused thalassemic patients and re infection with different strain (17).

\section{Materials and Methods}

The study was carried out on 111 transfusion dependent beta-thalassemia (74 males and 37 females) with a mean age 12.51 yrs attending to the Ibn - Albalady Hospital, in Baghdad. All patients selected randomly. The control group was thirty - one (12 males and 19 females) with mean age of $11.5 \mathrm{yrs}$ were investigated to serve as a control group; they were randomly selected from community. Blood sample were collected in morning used for biochemical assays (anti $\mathrm{HCV} \quad \mathrm{Ab}, \quad$ GOT,GPT,ALP,TSB, Dir.SB,Indir.SB). HCV was determined using the (bioelisa, spain). GOT and GPT was determined using the transaminases kit (Bio merieux Sa, France) and ALP was determined using the phosphates alkaline kit (Bio merieux
Sa, Farnce). TSB, Dir.SB and Indir. SB was determined using kit (linear, Spain).

Data were analyzed using the computer facility - the available statistical packages of SPSS-11.5 (statistical packages for social sciences-version 11.5).Data was presented in simple measures of number, percentage, mean, $\mathrm{SD}$, range (min-max). The significance of difference between quantitative variables was tested using student t-test for comparing between two means of independent groups. Chi-square test $\chi^{2}$ was used to test the significance of the qualitative data. $\mathrm{P}$ value equal and less than 0.05 was used as the level of significance.

\section{Results}

Serum sample from 111 thalassemic patients was screened and confirmed for serum HCV antibodies. Out of 111 thalassemic patients there was $51(46 \%)$ sera was confirmed positive for anti- $\mathrm{HCV}$ - antibodies. The remaining $60(54 \%)$ were seronegative, while among 31 healthy controls only one (3.22\%) was seropositive. The result was statistically a highly significant difference $(\mathrm{P}=0.0001)$ as shown in Table (1).

The distribution of $\mathrm{HCV}$ seropositive according to age group shows that there was an increase in rate of infection with age of the patients. Out of 51 seropositive, $13(72.3 \%)$ patients were positive among those above 20 years, while only one (16.7) was positive among those from $(0-4)$ years. This result was statistically a highly significant difference $(\mathrm{P}=0.01)$, as shown in Table (2).

Out of 51 affected patient, $37(50.0 \%)$ were males and $14(37.7 \%)$ were females, this result was statistically not significant, as shown in Table (2).

Our study has demonstrated a higher mean value of TSB in patients with $\mathrm{HCV}$ seropositive, but the results does not show a significant difference between patients with $\mathrm{HCV}$ seropositive and patients with $\mathrm{HCV}$ seronegative. A similar result was observed in fraction of indirect serum bilirubin. However, the fraction of direct serum bilirubin was statistically a highly significant difference, as it shown in Table (3).

The current study demonstrated that there was a highly significant difference in GPT 
levels between patients with HCV seropositive and patients with HCV seronegative $(\mathrm{P}=0.002)$. Also, less significant difference in GOT and ALP level as it shown in Table (4).

Table (1)

Frequency of HCV seropositivity among patients and controls.

\begin{tabular}{|c|c|c|c|c|c|}
\hline & \multicolumn{2}{|c|}{$\begin{array}{c}\text { HCV } \\
\text { antibodies } \\
\text { positive }\end{array}$} & \multicolumn{2}{|c|}{$\begin{array}{c}\mathrm{HCV} \\
\text { antibodies } \\
\text { negative } \\
\end{array}$} & \multirow[t]{2}{*}{ Total } \\
\hline & No & $\%$ & No & $\%$ & \\
\hline Patients & 51 & $(46 \%)$ & 60 & $(54 \%)$ & 111 \\
\hline Controls & 1 & $(3.22 \%)$ & 30 & $(96.77 \%)$ & 31 \\
\hline \multicolumn{6}{|c|}{001} \\
\hline
\end{tabular}

Table (2)

Distribution of $\mathrm{HCV}$ positive and $\mathrm{HCV} \rightarrow \mathrm{ve}$ among patient according age and sex.

\begin{tabular}{|c|c|c|c|c|c|}
\hline \multirow[t]{2}{*}{ Variable } & \multicolumn{2}{|c|}{$\begin{array}{l}\text { Patient with } \\
\text { HCV +ve }\end{array}$} & \multicolumn{2}{|c|}{$\begin{array}{c}\text { Patient with } \\
\text { HCV -ve }\end{array}$} & \multirow{2}{*}{$\begin{array}{c}\mathbf{P} \\
\text { Value }\end{array}$} \\
\hline & No & $\%$ & No & $\%$ & \\
\hline \multicolumn{6}{|c|}{ Age (years) } \\
\hline $0-4 \mathrm{n}=6$ & 1 & $16.7 \%$ & $\overline{5}$ & $38.3 \%$ & \multirow{6}{*}{0.01} \\
\hline $5-9 n=30$ & 8 & $26.7 \%$ & 22 & $\begin{array}{ll}73.3 \% \\
\end{array}$ & \\
\hline $\begin{array}{l}10-14 \\
n=46\end{array}$ & 22 & $47.8 \%$ & 24 & $\begin{array}{l}52.5 \% \\
\end{array}$ & \\
\hline $\begin{array}{l}15-19 \\
n=11\end{array}$ & 77 & $63.6 \%$ & 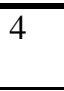 & $36.4 \%$ & \\
\hline $\begin{array}{l}\geq 20 \\
n=18\end{array}$ & 13 & $72.3 \%$ & $\overline{5}$ & $27.7 \%$ & \\
\hline $\begin{array}{l}\text { Total } \\
\mathrm{n}=111\end{array}$ & 51 & $45.9 \%$ & $\overline{60}$ & $\begin{array}{ll}54.1 \% \\
\end{array}$ & \\
\hline \multicolumn{6}{|l|}{ Sex } \\
\hline $\begin{array}{l}\text { Male } \\
n=74\end{array}$ & $\overline{37}$ & $72.5 \%$ & 37 & $\begin{array}{ll}50.0 \% \\
\end{array}$ & \multirow{3}{*}{ N.S } \\
\hline $\begin{array}{l}\begin{array}{l}\text { Female } \\
\mathrm{n}=37\end{array} \\
\end{array}$ & 14 & $27.5 \%$ & 23 & $62.2 \%$ & \\
\hline $\begin{array}{l}\text { Total } \\
n=111\end{array}$ & 51 & $45.9 \%$ & $\overline{60}$ & $\begin{array}{ll}54.1 \% \\
\end{array}$ & \\
\hline
\end{tabular}

Table (3)

Serum bilirubin levels ( $\mu$ mol/l) between patient with $\mathrm{HCV}+v e$ compared with Table $\mathrm{HCV}-\mathrm{ve}$.

\begin{tabular}{|c|c|c|c|c|c|}
\hline \multirow[t]{2}{*}{ Variables } & \multicolumn{2}{|c|}{$\begin{array}{c}\text { Patients with } \\
\text { HCV + ve }\end{array}$} & \multicolumn{2}{|c|}{$\begin{array}{c}\text { Patient with } \\
\text { HCV -ve }\end{array}$} & \multirow{2}{*}{$\begin{array}{c}\mathbf{P} \\
\text { Value }\end{array}$} \\
\hline & Mean & \pm SD & Mean & \pm SD & \\
\hline TSB & 35.85 & 29.90 & 28.86 & 25.08 & N.S \\
\hline Dir.SB & 9.484 & 5.233 & 5.296 & 5.036 & 0.0001 \\
\hline Indir.SB & 26.11 & 26.23 & 23.57 & 21.14 & N.S \\
\hline
\end{tabular}

Table (4)

Serum COT, GPT and ALP levels between patient with $\mathrm{HCV}+v e$ compared with $\mathrm{HCV}-\mathrm{ve}$.

\begin{tabular}{|c|c|c|c|c|c|}
\hline \multirow{2}{*}{ Variables } & \multicolumn{2}{|c|}{$\begin{array}{l}\text { Patients with } \\
\text { HCV +ve }\end{array}$} & \multicolumn{2}{|c|}{$\begin{array}{c}\text { Patient with } \\
\text { HCV -ve }\end{array}$} & \multirow{2}{*}{$\begin{array}{c}\mathbf{P} \\
\text { Value }\end{array}$} \\
\hline & Mean & \pm SD & Mean & $\pm \mathrm{SD}$ & \\
\hline GOT & 79.92 & 25.58 & 67.92 & 30.90 & 0.02 \\
\hline GPT & 50.65 & 23.03 & 36.82 & 23.21 & 0.002 \\
\hline ALP & 136.0 & 59.43 & 133.5 & 45.5 & N.S \\
\hline
\end{tabular}

\section{Discussion}

Surveys on thalassemic patients worldwide have found variable rates of anti- $\mathrm{HCV}$ antibody seroprevalence. Our study showed that the prevalence of $\mathrm{HCV}$ antibodies was higher among thalassemic patients (46\%), and the statistical analysis shows a highly significant difference $(\mathrm{P}=0.0001)$, this was nearly similar to another study done by ELNanway et. al, 1995 (18) who found that the prevalence of HCV in Egypt was $44 \%$. However, another study done in Iraq in Najaf city by Majeed, 2002 (19) found that the prevalence of $\mathrm{HCV}$ in thalassemic children was $15 \%$, this was probably due to the patients' age. Moreover, Iraqi thalassemic patients have demonstrated a higher rate compared with other countries such as in Jordan 40.7\% (14), in Saudi Arabia 40\% (11). It would be interesting to find out whether age and geographical differences could account for such variations. Notably, differences in sample size and the introduction of blood donor 
screening with restricted policy in other countries may result in a lower prevalence than that reported in the current study. On the other hand, another study done by Chakravarti et.al, 2005 (20) who found that the prevalence of $\mathrm{HCV}$ infection was (60\% and 63.8\%) respectively. As well as another study done in Iraq by Al - Kubaisy et.al, 2003(21), who found that the seroprevalence of $\mathrm{HCV}$ antibodies among multi-transfused thalassemic patients was $67.2 \%$. This may be related to large sample size conducted in study.

Our study demonstrated that there is a significant increase in rate of $\mathrm{HCV}$ infections with increasing age. This result is compatible with other study performed by Majeed, 2002 (19). The higher anti-HCV prevalence in older age groups may reflect the effect of increase exposures to $\mathrm{HCV}$ because increase blood transfusion during their life.

In our study, the anti-HCV antibodies were positive in 51(45.9\%) patients; male cases were $37(72.5 \%)$, females were 14 (27.5\%). This may lead to high prevalence of $\mathrm{HCV}$ antibody in males, but the result was not significant. Probably because of younger age females included in this study exclude an additional need for blood transfusion in pregnancy and other related gynecological problems.

Our study had demonstrated a higher mean value of TSB, but there was no significant difference in TSB between patients with a positive $\mathrm{HCV}$ antibody and patients with $\mathrm{HCV}$ negative. A similar result was obtained about the indirect serum bilirubin. However, the direct bilirubin fraction showed statistically a high significant difference. These findings agreed with another study done by Chakravarti et.al, 2005 (20) who found that the bilirubin levels were not significantly altered in these patients. This findings were in contrast to other findings reported by Sarkis, (2000 (22) who stated that there was a higher mean value of total serum bilirubin and a highly significant difference between patients with HCV positive and patients with HCV seronegative.This was probably because the increase of direct serum bilirubin among hepatitis $\mathrm{C}$ positive patients is expected to be reflected as elevation of TSB as well but this can be masked by equal levels of unconjugated bilirubin in both groups.
Our result had demonstrated that the mean value of GPT, for example was $(50.65 \pm 23.0$ $\mathrm{U} / \mathrm{L}$ ) in $\mathrm{HCV}$ positive cases, compared to $(36.82 \pm 23.21 \mathrm{U} / \mathrm{L})$ in $\mathrm{HCV}$ negative cases, and the difference statistically was significant $(\mathrm{P}=0.002)$. This was compatible with other studies Wanachiwanawin et.al, 2003 (23) which all reported that the patients with antiHCV antibodies had significantly abnormal level of serum GPT compared with patients without anti-HCV antibodies. Shindo et. al, 1995 (24).

Found that anti-HCV positive patients who have elevated serum GPT level are more likely to have a significant liver disease than those who have normal serum GPT level. Serum GPT elevation in anti-HCV positive individuals suggests the presence of liver damage such as viral replication (25) and iron overload (26).Our results have also demonstrated that there was significant difference in GOT between patients with $\mathrm{HCV}$ seropositive and patients with $\mathrm{HCV}$ seronegative $(P=0.02)$. Similar results were reported by Al-Sheyyab et. al, 2001 (14) who found that patients with anti-HCV antibodies had significantly abnormal GOT compared to patients without anti-HCV antibodies $(\mathrm{P}=0.02)$. In addition, other results performed by $\mathrm{Al}$ - Hawsawi,2000 (11) who found that there was a highly significant difference in GOT level between thalassemic patients with $\mathrm{HCV}$ seropositive and patients with $\mathrm{HCV}$ seronegative. Our results demonstrated that there was not significant difference in ALP activity between patients with $\mathrm{HCV}$ seropositive and patients with HCV. This was compatible with other finding reported by AlHawsawi, 2000 (11). This was probably because ALP is expected to increase in obstructive jaundice rather than hepatocellular jaundice, which was expected in hepatitis $\mathrm{C}$ virus infection.

\section{References}

[1] Hoffbrand, A.V.; Pettit, J.E. and Moss, P.A.H. (2001). Essential Haematology. $4^{\text {th }}$ ed. Blackwell Science. Oxford.

[2] Noguchi, C.T.; Butterwoth, J.R.; Karawajew, L.; Küppers, R.; Favaloro, E; and Jacobsohn, D. (2004). Reducing oxidative damage and cell dehydration in 
thalassemia. Haematologica. 89:12811283.

[3] Al - Awamy, B.H. (2000). Thalassemia syndromes in Saudi Arabia, review articles. Saudi. Med. J. 21: 8 - 17.

[4] Weatherall, D.J. (2000). Disorders of the synthesis or function of haemoglobin. In: Ledingham, J.G. and Warrell, D.A (Eds). Concise Oxford text book of medicine. $1^{\text {st }}$ ed. Oxford University Press.

[5] Al-Hawsawi, Z.M.; Ismail, G.A.; Al-Harbi, H.A.; and Al - Sobhi, Z.R. (2003). B- Thalassemia major. Saudi.Med.J. 24(9): 1027 - 1029.

[6] Haslett, C.; Chilvers, E.R.; Boon, N.A.; and Colledge, N.R. (Eds). (2002). Davidson's principles and practice of medicine. $19^{\text {th }}$ ed. Churchill Livingstone. London.

[7] Hendricks, L.K. (2003). Thalassemia, Alpha. Available at www.emedicine.com.

[8] Behrman, R.E.; Kliegman, R.M.; and Jonson, H.B. (2000). Nelson text book of pediatrics. $16^{\text {th }}$ ed. U.S.A: W.B Saunders Company.

[9] Baysal, E.; and Carver, M. (1995). The band $\delta$ thalassemia repository. Hemoglobin. 13: 213.

[10] Takeshita, K. (2002). Thalassemia, Beta. Available at www.emedicin.com.

[11] Al - Hawsawi, Z.M. (2000). Prevalence of $\mathrm{HCV}$ antibodies. Annals of Saudi.Med. 20: $5-6$.

[12] Minola, E.; Parti, D.; Sauter, F.; Maggiolo, F.; Caprioli, F.; Sonzogni, A.; Mirella, F.; Paggi, S.; and Conte, D. (2002). Age at infection affects the long term outcome of transfusion associated chronic hepatitis C. Blood. 99(12): 4588 - 4591.

[13] Alter, M.J.; Hadler, S.C.; Judson, F.N.; et.al. (1990). Risk factor acute non-A, non$B$ hepatitis in the United State and association with hepatitis infection. JAMA. 264: $2231-35$.

[14] Al - Sheyyab, M.; Batieha, A.; and El Khateeb, M. (2001). The prevalence of hepatitis $\mathrm{B}$, hepatitis $\mathrm{C}$ and human immune deficiency virus markers in multitransfused patients. J.Trop. Pediatr. 47: 239-242.
[15] Zurlom, G.; Stefano, P.; Borgna, P.C.; and etal. (1989). Survival \& causes of death in thalassemia major. Lancet. 11: $27-30$.

[16] Donohue, S.M.; Wonke, B.; Hoffbrand, A.V.; Reittie, J. Ganeshaguru, K.; Scheuer, P.J.; Brown, D.; and Dusheiko, G. (1993). Alpha interferon in treatment of chronic hepatitis infection in thalassemia major. British.J.Heamatology. 83(3): 491 - 97.

[17] Lai, M.E.; De Virgilis, S.; Argioulu, F.; Farci, P.; Mazzoleni, A.P.; Lisci, V.; Rapicetta, M.; Clemente, M.G.; Nurchis, P.; and Arnone, M. (1993). Elevation of antibodies of hepatitis $\mathrm{C}$ virus long term prospective study of post-transfusion hepatitis among thalassemic children: comparison between first \& second generation assay. J.Pedia. Gastroenterol. Nutr. 16(4): $458-64$.

[18] El-Nanaway, A.A.; El-Azzoceni, O.F.; Soliman, A.T.; et.al. (1995). Prevalence of $\mathrm{HCV}$ antibodies seropositivity in Healthy Egyptian children and four high risk groups. J.Trop.Pediatr. 41(6): $341-3$.

[19] Majeed, M.N. (2002). Prevalence of hepatitis B and hepatitis C infections among thalassemic children in Najaf city. Kufa.Med. 5(1): $192-6$.

[20] Chakravarti, A.; Verma, V.; Kumaria, R.; and Dubey, A.P. (2005). Anti- HCV seropositivity among multiple transfused patients with beta thalassemia. Indian. Med. Assoc. 103(2): $64-6$.

[21] Al - Kubaisy, W.; Habib, M.A.; and Al-Naib, K.T. (2004). Serum alanine aminotransferase level among thalassemic children infected with hepatitis $\mathrm{C}$ virus. Al-Kindy.Col.Med.J. 2(1): $55-60$.

[22] Sarkis, K.S. (2000). Prevalence of hepatitis $\mathrm{C}$ virus in patients with hemoglobinopathies in Basrah. Med. J.Basrah. Univ. 18(1): $32-7$.

[23] Wanachiwanawin, W.; Luengrojanakul, P.; Sirangkapracha, P.; Leowattana, W.; and Fucharoen, S. (2003). Prevalence and clinical significance of hepatitis $\mathrm{C}$ virus infection in this patient with thalassemia. Int.J.Hematol. 78(4): $374-8$.

[24] Shindo, M.; Arai, K.; SoKawa, Y.; and Okuno, T. (1995). The virolo and histological status of anti hepatitis $\mathrm{C}$ virus 
positive subjects with normal liver biochemical values. Hepatol. 22: $418-25$.

[25] Maio, G.; d'Arginio, P.; Streffolini, T.; Bozza, A.; Saco, L; Tosti, M.E.; Introcia, M.; Fossi, E.; d'Alessio, G.; Kondili, L.A.; Rapicetta, M.; and Mele, A. (2000). Hepatitis C virus infection, alanine transaminase level in the general population: a survey Southern Italian town. J.Hepato. 33(1): $116-20$.

[26] Prati, D.; Zanella, A.; Farma, E.; De Mattei, C.; et.al. (1998). Amulti- center prospective study on the risk of acquiring liver disease in anti- HCV negative patients affected from homozygous $\beta$-thalassemia. 92: $3460-66$.

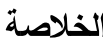

خلقية البحث 'يعد مرض الثلاسيميا (مرض فقر الدم البحسر

المتوسط) واحدا من اكثر الامر اض خطورة وهو عبارة عن خلل ور اثي في انتاج الهيمو غلوبين (خضاب الدم) اي فــشل الهن كلي او جزئي في انتاج سلاسل الكلوبين . هدف البحث : هدف هذة الدراسة هو بيـان مــدى انتـشار مرض التهاب الكبد لفايروسي C بين مرضــى الثثلاسـيميا (مرض فقر الدم البحر الابيض المتوسط) في مستثفى ابــن لئن البلدي في بغداد.

المرضى وطريقة العمل : شملت الدراسة 111 مريض مسن بـن نوع بيتا ثلاسيميا (74 ذكور و 37 اناث) بمتوسط عدــري

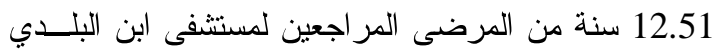

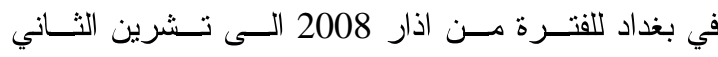

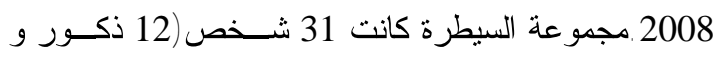
19 اناث) الذين ييدون اصحاء حيث تم اختيار هم بـصورة

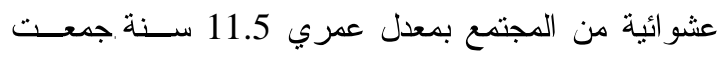

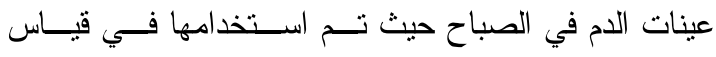

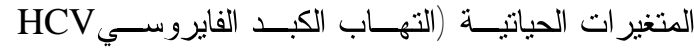
،انزيمات الكبد GOT, GPT, ALP ووضـائف الكبـــ . (TSB, Dir.SB, Indir.SB

النتائج: اضــهرت هذةالدر اسـة (46) 51 مسن 111

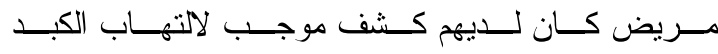

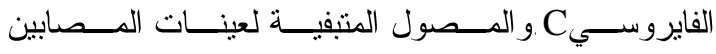

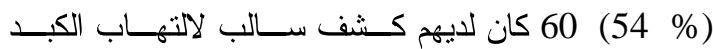

الفايروسي C. Cاما عينات السيطرة فاظهرت نتائج التحاليـلـ عدم اصابتهم بالتهاب الكبد الفايروسي C عدا عينة واحسـدة

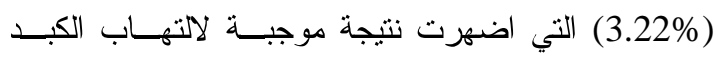
الفايروسي C. Cلنتائج الاحصائية بين مرضــى الثلاسـيميا

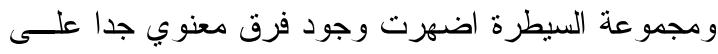

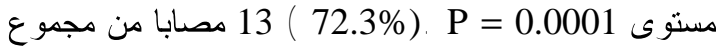

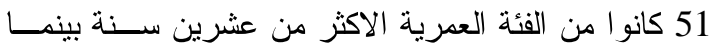
كانت عينة واحدة مصابة(16.7) كانت ضمن الفئة العمرية



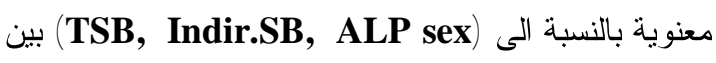
المرضى المصابين و الغير مصابين بالتهاب الكبد الفايروسي

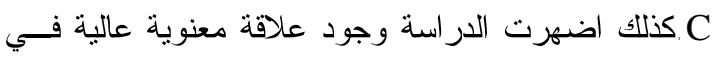
بين المرضى المصابين (GPT, GOT, and Dir.SB) و الغير مصابين بالتهاب الكبد الفايروسيC.

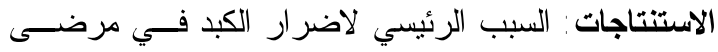

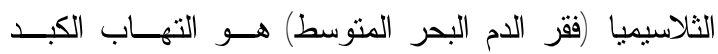

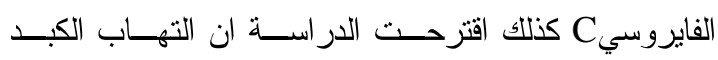

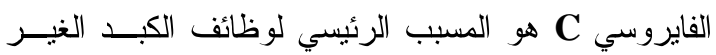

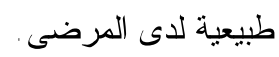

